\title{
O CANCIONEIRO DA EMIGRAÇÃO ITALIANA: POESIA ORAL RESSIGNIFICADA NA PERFORMANCE
}

The song of italian emigration: oral poetry resignified by performance

Na poesia se aninha a esperança de que um dia uma palavra dirá tudo. $O$ canto exalta essa esperança, e emblematicamente a realiza. Isso porque a poesia oral dá à voz sua dimensão absoluta; à linguagem humana, sua medida máxima.

(ZUMTHOR, 2010, p. 295)

Carina Fior Postingher BALZAN ${ }^{1}$

IFRS

cfpbalzan@gmail.com

Rafael José dos SANTOS ${ }^{2}$

UCS

rafaprof@gmail.com

${ }^{1}$ Mestre em Letras, Cultura e Regionalidade pela Universidade de Caxias do Sul (UCS). Aluna do Programa de Doutorado em Letras (associação ampla UCS/UniRitter). Docente do Instituto Federal de Educação, Ciência e Tecnologia do Rio Grande do Sul - Campus Bento Gonçalves.

${ }^{2}$ Doutor em Ciências Sociais (UNICAMP) com estágio pós-doutoral em Letras (UFRGS). Docente e pesquisador no Programa de Pós-Graduação em Letras, Cultura e Regionalidade (UCS) e no Doutorado em Letras (Associação ampla UCS/UniRitter).

Revista TextoPoético | ISSN: 1808-5385 | Vol. 21 (2o sem-2016) - p. 27. 
RESUMO: O artigo aborda o cancioneiro popular italiano representativo da emigração para a América, ocorrida no fim do século XIX, tomando por base teórica os conceitos de Zumthor (1993, 2007, 2010) sobre poesia oral, vocalidade, performance e movência. Procura discutir como essas canções são atualizadas e ressignificadas no momento da performance, transpondo a circunstância histórica em que foram produzidas. Ao serem trazidas para o Brasil pelos migrantes, algumas caíram no esquecimento, outras originaram novas versões que garantiram sua permanência na memória do grupo social. Para tal análise, foram selecionadas duas canções performatizadas por Caterina Bueno, intérprete e pesquisadora que se dedicou à coleta e recuperação da música popular italiana.

Palavras-chave: Cancioneiro popular italiano. Vocalidade. Performance.

ABSTRACT: The paper discusses the Italian popular song that represents the emigration to America, which took place at the end of 19th Century, taking as theoretical basis the concepts of Zumthor (1993, 2007, 2010) on oral poetry, vocality, performance and mouvance. This work discusses how these songs are updated and re-signified at the time of performance, crossing the historical circumstances in which they were produced. To be brought to Brazil by migrants, some fell by the wayside, others originated new versions that ensured their permanence in the memory of the social group. For this analysis, we selected two songs by Caterina Bueno, interpreter and researcher who dedicated to the collection and recovery of Italian popular music.

Keywords: Italian popular song. Vocality. Performance.

\section{Introdução}

Desde o surgimento da escrita e, de forma mais sistemática, com o advento da imprensa de Gutenberg e a posterior industrialização da impressão, disseminou-se a ideia de que a utilização de um código para fixar determinada informação, dado ou saber garantiria sua perenidade, desonerando cada vez mais a memória da função de guardiã do conhecimento. Na atual sociedade ocidental, a escrita constitui, de fato, a forma "privilegiada" de

Revista TextoPoético | ISSN: 1808-5385 | Vol. 21 (2o sem-2016) - p. 28. 
comunicação; o domínio de um código e sua decodificação através da leitura constitui um saber que, em princípio, garantiria ao indivíduo a autonomia necessária para mover-se e atuar no mundo letrado.

Nessa perspectiva, a escrita (e, consequentemente, a leitura) transforma-se em fator de segregação social, visto que nem todos os indivíduos, apesar da escolarização ter se popularizado nos últimos dois séculos, têm oportunidade de se apropriar desse saber. A este segmento da população que não participa dos "benefícios" que a escrita e a leitura possibilitam resta-lhe a oralidade, considerada (velada ou abertamente) uma forma efêmera, mutável e inferior, cujos saberes e conhecimentos, confiados à memória, são transmitidos de geração a geração.

Esses pressupostos foram suficientes para se atribuírem os préconceitos de "sociedade primitiva" ou "cultura popular" aos grupos sociais que vivem em caráter de oralidade pura ou que não têm na escrita sua forma predominante de comunicação, reflexo das tensões entre cultura hegemônica e culturas subalternas. Pela imprecisão do termo "popular", expressões como cultura popular, literatura popular ou música popular também foram associadas à oralidade em oposição à escrita, aos produtos culturais do povo, ou melhor, da parte mais pobre de uma nação em oposição à elite, rica e esclarecida.

A própria literatura foi legitimada pela escrita, a qual the conferiu uma materialidade (através do livro), uma autoria (propriedade de autor) e uma perenidade, fixando, a partir de um código, o texto a ser mantido original através do tempo e do espaço. Por muito tempo excluiu-se dos estudos literários a literatura oral que, guardada pela memória, pode não ter assegurada sua Revista TextoPoético | ISSN: 1808-5385 | Vol. 21 (2o sem-2016) - p. 29. 
permanência no tempo, tornando-se extremamente volátil em suas formas.

É justamente para criticar essa definição contemporânea de literatura, vinculada ao texto escrito, à leitura individual e silenciosa e a uma cultura livresca, que Zumthor utiliza o termo "literatura", com aspas, apontando para uma ideia mais ampla da manifestação poética da palavra, tomada como uma arte da linguagem humana, independente de seus modos de concretização, e englobando outros elementos além da linguagem escrita (FALBO, 2010).

Parece um exercício difícil, a partir do contexto atual, olhar para o passado e perceber que a oralidade foi, por milênios, o meio que garantiu se não a sobrevivência, pelo menos a unicidade da espécie humana, permitindo a transmissão dos saberes, a construção de valores, a expressão dos sentimentos, a vazão das emoções. Contos e outras formas de narrativas, epopeias, poemas e canções constituíram, na definição de Zumthor, uma poesia oral viva, que a voz se encarregou de propagar:

Já há muito tempo, com efeito, em nossas sociedades a paixão da palavra viva se extinguiu [...]. Em razão de um antigo preconceito em nossos espíritos e que performa nossos gostos, todo produto das artes da linguagem se identifica com uma escrita, donde a dificuldade que encontramos em reconhecer a validade do que não o é. Nós, de algum modo, refinamos tanto as técnicas dessas artes que nossa sensibilidade estética recusa espontaneamente a aparente imediatez do aparelho vocal. (ZUMTHOR, 2010, p. 9).

Os pressupostos teóricos de Zumthor sobre literatura e poesia oral permitem desconstruir alguns conceitos já enraizados nos estudos literários, oferecendo-nos uma nova perspectiva para o texto, ampliando o alcance da palavra para além do escrito: a palavra

Revista TextoPoético | ISSN: 1808-5385 | Vol. 21 (2o sem-2016) - p. 30. 
vocalizada em diferentes contextos, seja ela cantada, recitada ou encenada. $\mathrm{O}$ autor concebe o suporte vocal como realizador da linguagem e como fato físico-psíquico próprio, ultrapassando a função linguística.

É a partir desta perspectiva teórica que abordamos, neste artigo, o cancioneiro popular da emigração italiana, representado por duas canções performatizadas por Caterina Bueno ${ }^{3}$.

\section{Poesia oral e vocalidade no cancioneiro popular italiano}

É preciso explicitar, primeiramente, o que se entende por poesia oral. Zumthor propõe pensar a poesia e, portanto, a própria literatura no sentido de sua literariedade, desvinculando-a de critérios estéticos. Para o autor,

É poesia, é literatura, o que o público - leitores ou ouvintes - recebe como tal, percebendo uma intenção não exclusivamente pragmática: o poema, com efeito (ou, de uma forma geral, o texto literário), é sentido como a manifestação particular, em um dado tempo e em um dado lugar, de um amplo discurso constituindo globalmente um

${ }^{3}$ Filha de artistas estrangeiros que se instalaram na Toscana em 1940, o pai, um pintor espanhol, e a mãe, uma escritora suíça, Caterina Bueno nasceu e cresceu em San Domenico di Fiesole. Até os vinte e um anos manteve a cidadania espanhola. $O$ vínculo com as canções dos camponeses toscanos estabeleceu-se ainda na infância, no convívio com a babá, que lhe cantava canções de ninar. Ao fascínio pela sonoridade e expressões linguísticas daquelas canções juntaram-se algumas questões sociais que a incomodavam: a injustiça social, a pobreza, a posição das mulheres, características da situação pós-guerra que a Itália, e a Europa como um todo, enfrentavam. Ainda na juventude, Caterina inicia um trabalho de coleta e registro dessas canções, recuperando um patrimônio cultural ameaçado de desaparecer (GIORGI; SPINELLI; MASOLINI, 2013).

Revista TextoPoético | ISSN: 1808-5385 | Vol. 21 (2o sem-2016) - p. 31. 
tropo dos discursos usuais proferidos no meio do grupo social. (ZUMTHOR, 2010, p. 39).

Nesse sentido, na poesia oral, os procedimentos de gramaticalização têm menos força que a dramatização do discurso, ou seja, os elementos linguísticos têm menos peso que os sociológicos. Isso não significa que a poesia oral possua uma estrutura menos complexa que a escrita. $\mathrm{Na}$ verdade, não se pode pensá-la em oposição à escrita, tampouco relacioná-la a analfabetismo, mesmo que na atualidade a oralidade não cumpra mais a função que cumpria para nossos antepassados.

$\mathrm{Na}$ poesia oral há uma intencionalidade de expressão, por parte do emissor, que vai além da comunicação referencial. Concorrem para a construção da mensagem, além da linguagem, os aspectos sensoriais e psíquicos. O receptor percebe essa intenção e recebe enquanto tal a mensagem, como algo que transpõe a barreira do real cotidiano, palpável, mas que se eleva ao campo dos sentimentos. A poesia oral é percebida como um "vasto concerto de sonoridades agradáveis, harmoniosas ou discordantes, um jogo vocal que recobre o ruído comum da vida [...]" (ZUMTHOR,1993, p. 146).

A linguagem é impensável sem a voz, mas a voz ultrapassa a palavra porque "a voz se diz enquanto diz". Forma arquetipal, a voz configura-se em nosso inconsciente como imagem primordial e criadora, despertando-nos os sentidos mais profundos, a própria condição humana:

O Verbo, força vital, vapor do corpo, liquidez carnal e espiritual, no qual toda atividade repousa, se espalha no mundo ao qual dá vida. [...] Verticalidade luminosa brotando das trevas interiores, ainda marcada, todavia, por estes sulcos profundos, a palavra proferida pela Voz cria o que diz. Ela é justamente aquilo que chamamos

Revista TextoPoético | ISSN: 1808-5385 | Vol. 21 (2o sem-2016) - p. 32. 
poesia. Mas ela é também memória viva, tanto para o indivíduo (para quem a imposição do seu nome deu forma), quanto para o grupo, cuja linguagem constitui a energia ordenadora. (ZUMTHOR, 2010, p. 66).

A oralidade, contudo, não se reduz à ação da voz. Ela é uma extensão do próprio corpo, em que cada gesto significa, integrandose a uma poética (ZUMTHOR, 2010). Ligada à materialidade do corpo, a voz explicita traços pessoais e culturais, estabelecendo ou restabelecendo uma relação de alteridade, que funda a palavra do sujeito. Na voz, portanto, está inscrita a identidade de quem a emite (ZUMTHOR, 2007).

Manifestação expressiva da voz humana, a vocalidade exige o empenho do corpo. Um corpo pleno de sentidos, físico-psíquico, material e espiritual. Um corpo que, ao mesmo tempo em que sente, se expressa por meio da voz. E uma das formas mais plenas da vocalidade é o canto. No uso comum da língua, o falado utiliza apenas uma pequena parte dos recursos da voz. O papel do órgão vocal restringe-se a emitir sons audíveis de acordo com as regras de um sistema fonético que não procede de exigências fisiológicas. No canto, como também na declamação ou na encenação, a voz explora o volume, o tom, a duração e o timbre, criando uma sonoridade própria, portadora de sentido, uma arte da voz:

Dita, a linguagem submete-se à voz; cantada, ela exalta sua potência, mas, por isso mesmo, glorifica a palavra... mesmo ao preço de um obscurecimento do sentido, de uma certa opacificação do discurso: exaltada menos como linguagem que como afirmação da potência. (ZUMTHOR, 2010, p. 199).

Não apenas a voz, mas o corpo todo significa ao cantar: a respiração, a expressão facial, a gestualidade, os demais aspectos

Revista TextoPoético | ISSN: 1808-5385 | Vol. 21 (2o sem-2016) - p. 33. 
visíveis, como a vestimenta ou a ornamentação, e os que podem ser percebidos, como o estado emocional, o estilo, a personalidade do intérprete. Um conjunto de elementos extratextuais une-se ao texto/letra da canção para criar uma significação.

É nessa perspectiva que tomamos as canções populares italianas abordadas neste estudo como formas de poesia oral. Não nos detemos na análise textual, tampouco desvinculamos a letra da melodia, mas as entendemos enquanto obra, na definição de Zumthor (2010, p. 84), “[...] aquilo que é comunicado poeticamente, aqui e neste momento: texto, sonoridades, ritmos, elementos visuais", contemplando a totalidade dos fatores da performance.

\section{Caterina Bueno: a voz do cancioneiro popular}

Anterior ou independente da escrita, a canção nasce de uma necessidade de expressão que se pretende compartilhar. Acompanhada ou não de instrumentos musicais, a voz materializa o sentir-pensar de um indivíduo ou de um grupo manifestado em determinada circunstância sócio-histórica. Todavia, pela sua potencialidade comunicativa, a canção constitui uma forma expressiva que ultrapassa as delimitações de tempo e espaço, que se transforma e se propaga para além da circunstância que a motivou, podendo ser ressignificada ou assumir uma nova função social:

A canção possui uma característica de versatilidade que lhe permitiu passar por diversas mudanças ao longo do tempo, assimilando novas tecnologias, novos padrões estéticos e novas funções sociais, mas sempre mantendo seu extraordinário poder comunicativo. Do universo tradicional dos acalantos, cantigas de roda e cantos de trabalho ao modismo descartável das paradas de sucesso, a canção é uma forma expressiva de ampla inserção

Revista TextoPoético | ISSN: 1808-5385 | Vol. 21 (2o sem-2016) - p. 34. 
social, seja por meio de sua transmissão oral ou por meio do rádio, da televisão, dos discos e dos shows. (FALBO, 2010, p. 218).

As canções Italia bella mostrati gentille e Il Sirio ${ }^{4}$, ambas presentes no trabalho musical de Caterina Bueno, são representativas de um momento singular da história da Itália: a emigração em massa para a América, ocorrida no final do século XIX. Um acontecimento que implicou profundas transformações na estrutura social italiana e repercutiu no Brasil, onde se estabeleceu grande parte dos emigrados.

Estima-se que, entre 1815 e 1914, cerca de 40 milhões de pessoas deixaram a Europa e emigraram para outros continentes (85\% para a América), possibilitando aos governos europeus encontrar uma nova estabilidade social para os abalos políticosociais provocados pelo alto crescimento demográfico, pela introdução do sistema capitalista de produção e o consequente fim do feudalismo.

No caso da Itália, segundo De Boni e Costa (1979), com o esfacelamento da pequena indústria de tipo artesanal, cujo produto complementava a renda familiar do agricultor, a elevação dos impostos e a redução dos preços dos produtos agrícolas, houve uma rápida deterioração da situação socioeconômica no campo. Muitos foram obrigados a vender suas terras ou, endividados, tiveram as propriedades leiloadas pelo governo, gerando um excedente populacional no campo cujas cidades não conseguiram absorver. As dificuldades recaíram também sobre a dieta alimentar da população

${ }^{4}$ Tomaram-se para análise as canções Italia bella mostrati gentille e Il Sirio gravadas em disco, ou seja, a performance mediatizada foi ouvida em áudio, sem a visualização da imagem.

Revista TextoPoético | ISSN: 1808-5385 | Vol. 21 (2o sem-2016) - p. 35. 
do campo que, sem condições de consumir carne, passou a alimentar-se de produtos à base de milho, gerando subnutrição e propensão a várias doenças.

Os efeitos da crise econômica fizeram-se sentir primeiramente no norte da Itália, onde teve início a grande emigração. O Piemonte, a Lombardia e o Vêneto foram as regiões de onde saíram os maiores contingentes de pessoas. A maioria eram agricultores que, coagidos a deixar o campo, não encontraram trabalho nas indústrias urbanas, restando-lhes poucas perspectivas de vida e transformando-se em um problema para o poder público local. A emigração foi, então, a melhor alternativa, não só para a população, como também para o governo:

Ao contrário do que se poderia supor, a emigração não significou, para as autoridades italianas e para as classes ricas, uma catástrofe. A curto prazo foi mesmo um alto negócio, pois carreou divisas, pelas mais diversas formas, e livrou o país de milhões de deserdados. Pode-se mesmo falar em uma indústria da imigração. (DE BONI; COSTA, 1979, p. 65, grifo dos autores).

Muitas canções surgiram motivadas por esse fato social. A voz foi o meio utilizado para expressar os sentimentos de indignação, revolta, tristeza e saudade experimentados por milhares de pessoas que se despediram não apenas de sua nação, mas de seus amigos e familiares para uma viagem sem volta, ao mesmo tempo em que cantavam a esperança de uma nova vida na América. Essa poesia oral propagou-se de geração a geração até a lembrança da grande emigração apagar-se lentamente da memória do grupo social, ou porque o fato social ficava cada vez mais distante no passado ou porque havia a intenção de esquecê-lo.

Revista TextoPoético | ISSN: 1808-5385 | Vol. 21 (2o sem-2016) - p. 36. 
É neste ponto que se destaca o trabalho de Caterina Bueno. Sua pesquisa, iniciada nos anos 1960 e marcada pelo rigor filológico, dedicou-se a coletar textos e melodias da voz de agricultores e trabalhadores sazonais, afirmando-a como referência do cancioneiro popular italiano. Equipada com um gravador e um caderno de anotações, Caterina atravessou a Toscana em busca de canções populares, registrando, reagrupando e transcrevendo as gravações de áudio, com respeito ao registro dialetal. Entre essas canções, estão cantigas de ninar e rimas infantis, canções de emigração, de guerra e de trabalho, canções relacionadas ao contexto social da segunda metade do século XIX, poemas que as pessoas cantavam para melhor suportar a miséria, o trabalho duro, a própria vida. Muitas dessas canções foram interpretadas por ela própria e gravadas em uma série de discos (GIORGI; SPINELLI; MASOLINI, 2013).

Em sua trajetória, Caterina não apenas recuperou um repertório musical oral, um patrimônio cultural, salvando-o do esquecimento, mas deu voz aos protagonistas dessa cultura. Ao ouvir suas canções, ao escutar-lhes as histórias de vida, Caterina ultrapassou a simples documentação, interagindo, dialogando com esses personagens, os quais fundaram sua concepção de música popular.

Italia bella mostrati gentille é uma das mais conhecidas canções da emigração italiana. Composta no final do século XIX, foi coletada por Caterina Bueno em 1965, em Casentino, província de Arezzo, na voz de Principio Micheli, que ainda jovem a cantava

${ }^{5}$ Essa canção encontra-se em dois álbuns de Caterina Bueno: Eran tre falciatori (1973) e Canti di Maremma e d'Anarquia (1997). Disponível em: $<\mathrm{http}: / /$ www.artistdirect.com/nad/window/media/page/0,35518598646514,00.html>. Acesso em: 20 jul. 2015.

Revista TextoPoético | ISSN: 1808-5385 | Vol. 21 (2o sem-2016) - p. 37. 
enquanto estava em Maremma, como trabalhador sazonal ${ }^{6}$. A obra, em tom satírico, revela o desespero de um povo, desolado pelas guerras e pela miséria, que é forçado a deixar o seu país para procurar trabalho do outro lado do oceano.

Italia bella mostrati gentille

Italia bella, mostrati gentille e i figli tuoi non li abbandonare, sennò ne vanno tutti ni' Brasile e 'un si rìcordon più di ritornare.

Ancor quà ci sarebbe da lavorà, senza stare in America a emigrà. Il secolo presente qui ci lascia, i' millenovecento s'avvicina.

La fame c'han dipinto sulla faccia e pe' guarilla 'un c'è la medicina. Ogni po' noi si sente dire: "E vo là dov'è la raccolta del caffè". Ogni po' noi si sente dire: "E vo là dov'è la raccolta del caffè".

L'operaio non lavora

e la fame lo divora, e qui 'i braccianti 'un san come si fare a andare avanti.

Spererem ni' novecento,

finirà questo tormento, ma questo è il guaio, il peggio tocca sempre all'operaio.
Itália bela mostra-te gentil ${ }^{7}$

Itália bela, mostra-te gentil e os filhos teus não os abandone, senão vão todos para o Brasil e não se lembrarão mais de retornar.

Aqui mesmo ter-se-ia no que trabalhar, sem ser preciso para a América emigrar. O século presente já nos deixa, e o mil e novecentos se aproxima.

A fome está estampada em nossa cara e para curá-la remédio não há.

A todo momento se ouve dizer: "E vou lá onde tem a colheita do café".

A todo momento se ouve dizer: "E vou lá onde tem a colheita do café".

O operário não trabalha

e a fome o devora,

e aqui os trabalhadores

não sabem como fazer para seguir em frente.

Esperaremos que no novecentos, acabará este tormento, mas este é o problema, o pior toca sempre ao operário.

${ }^{6}$ A migração sazonal e reversiva era uma prática comum na Itália, principalmente dos povos do norte, antes mesmo da grande emigração para a América. Em certas épocas do ano, os homens migravam para outras regiões e até mesmo para outros países da Europa em busca de trabalhos temporários.

${ }^{7}$ As letras de todas as canções apresentadas neste artigo foram traduzidas para a língua portuguesa por Vanessa Dal Cin.

Revista TextoPoético | ISSN: 1808-5385 | Vol. 21 (2o sem-2016) - p. 38. 
Ogni po' noi si sente dire: "E vo là dov'è la raccolta del caffè". Ogni po' noi si sente dire: "E vo là dov'è la raccolta del caffè".

Nun ci rimane più che preti e frati, monìcche di convento e cappuccini, e certi commercianti disperati

di tasse non conoscano confini.

Verrà un dì che anche loro dovran partì

là dov'è la raccolta del caffè. Verrà un dì che anche loro dovran partì

là dov'è la raccolta del caffè.

Ragazze che cercavano marito vedan partire il loro fidanzato. Vedan partire il loro fidanzato e loro restan qui co'i sor curato.

Verrà un dì che anche loro dovran partì là dov'è la raccolta del caffè.

Le case restan tutte spigionate, l'affittuari perdano l'affitto, e i topi fanno lunghe passeggiate, vivan tranquilli con tutti i diritti.

Verrà un dì che anche loro dovran partì là dov'è la raccolta del caffè. Verrà un dì che anche loro dovran partì là dov'è la raccolta del caffè.
A todo momento se ouve dizer: "E vou lá onde tem a colheita do café". A todo momento se ouve dizer: "E vou lá onde tem a colheita do café".

Não sobrou mais do que padres e frades, freiras de convento e franciscanos, e certos comerciantes desesperados de impostos não conhecem os limites.

Virá um dia que também eles deverão partir lá onde tem a colheita do café. Virá um dia que também eles deverão partir lá onde tem a colheita do café.

Garotas que procuravam marido veem partir o seu namorado. veem partir o seu namorado e elas ficam aqui com o senhor pároco.

Virá um dia que também elas deverão partir lá onde tem a colheita do café.

As casas ficam todas sem inquilino, os proprietários perdem o aluguel, e os ratos fazem longos passeios, vivem tranquilos com todos os direitos.

Virá um dia que também eles deverão partir lá onde tem a colheita do café. Virá um dia que também eles deverão partir lá onde tem a colheita do café.

Cantada em dialeto toscano, a canção expressa o sentimento da classe trabalhadora em relação à falta de assistência por parte do Revista TextoPoético | ISSN: 1808-5385 | Vol. 21 (2o sem-2016) - p. 39. 
governo italiano. Sem perspectiva de emprego, a miséria e a fome os impulsionam a emigrar para o Brasil a fim de trabalhar nas fazendas de café. As jovens perdem os namorados e, aos poucos, todos vão abandonando a Itália; até mesmo o clero se verá obrigado a partir.

Ao interpretá-la, a voz grave de Caterina Bueno intensifica o sentido do texto, elevando a canção a um hino de protesto. As duas estrofes declamadas (destacadas na letra em itálico) ecoam as vozes dos próprios operários, oprimidos pela classe dominante. $\mathrm{O}$ duplo refrão (destacado na letra em negrito) concorre para a produção de sentido, reforçando o significado das partes precedentes ou seguintes. $\mathrm{O}$ acompanhamento instrumental realizado basicamente com instrumentos de corda ressoa com o canto, e as duas músicas, da melodia e do texto, se unem na operação da voz.

Il Sírio ${ }^{8}$, registrado pela primeira vez por Michele Luigi Straniero (Il trágico naufrágio della nave Sirio), é uma canção típica dos contadores de história do norte da Itália, cujo texto provavelmente foi inscrito em folhetos volantes. Refere-se ao naufrágio do navio italiano Sirio na costa espanhola, ocorrido em 04 de agosto de 1906. Transportava 1700 emigrantes (provenientes das regiões do Vêneto e Trento) que saíram de Gênova com destino ao Brasil, Argentina e Uruguai. Cerca de 500 pessoas morreram ou ficaram desaparecidas. O comandante da embarcação foi preso, culpado pelo acidente por aproximar-se demais dos arrecifes para embarcar emigrantes clandestinos nas costas da Espanha.

${ }^{8}$ Essa canção encontra-se no álbum Canti di Maremma e d'Anarquia (1997), de Caterina Bueno. Disponível em: $<$ http://sonichits.com/album/Caterina_Bueno/Canti_di_Maremma_e_d'anarchia $>$. Acesso em: 20 jul. 2015.

Revista TextoPoético | ISSN: 1808-5385 | Vol. 21 (2o sem-2016) - p. 40. 


\section{Sírio}

E da Genova

in Sirio partivano

per l'America a varcare, varcare i confin.

Ed a bordo

cantar si sentivano,

tutti allegri del suo,

del suo destin.

Urtò il Sirio

un orribile scoglio.

Di tanta gente la misera, la misera fin.

Padri e madri

bracciava i suoi figli

che si sparivano tra le onde,

tra le onde del mar.

E fra loro

un vescovo c'era,

dando a tutti

la sua benedizion.

E fra loro (leri)

un vescovo c'era (lerà),

dando a tutti (leri)

la sua benedizion!

\section{O Sírio}

E de Genova

no Sírio partiam

para a América a transpor,

transpor os limites.

E a bordo

cantar se ouviam,

todos alegres por seu,

por seu destino.

Bateu o Sírio

num horrível arrecife.

De tanta gente o miserável, o miserável fim.

Pais e mães

abraçavam seus filhos

que desapareciam entre as ondas, entre as ondas do mar.

E entre eles

um bispo havia, dando a todos

a sua benção.

E entre eles (leri)

um bispo havia (lerà),

dando a todos (leri)

a sua benção!

No porto de Gênova, de onde embarcavam os emigrantes, iniciava a longa viagem para a América. A alegria, traduzida pelo canto, expressava a esperança de um recomeço. A tragédia no mar acabou com o sonho de muitos, marcando profundamente a história da emigração italiana e permanecendo na memória coletiva por muitas gerações. $\mathrm{O}$ sacerdote mencionado na canção era $\mathrm{o}$ 
Monsenhor José Camargo Barros, bispo de São Paulo, que retornava de uma viagem a Roma. De forma semelhante à canção anterior, a referência à Igreja Católica revela a força dessa instituição no contexto do grupo social.

$\mathrm{Na}$ performance dessa canção, entoada em coro, destaca-se a voz de Maurizio Geri, um dos músicos do grupo de Caterina Bueno ${ }^{9}$.O acompanhamento instrumental é também feito com instrumentos de corda, deixando em evidência as vozes dos intérpretes. Na análise de Caprara (1999), a repetição de lerì/lerá, nos últimos versos, sugere uma música celestial que acolherá os náufragos pela bênção que haviam recebido.

\section{Canções em performance: construção de novos significados}

Somente percebendo a obra oral em sua existência discursiva podemos apreender sua existência textual. Assim, como forma de poesia oral, a canção só se realiza plenamente em performance. É na execução da canção que se manifesta o sentido global, abrangendo, juntamente com o texto, múltiplos elementos significantes, auditivos, visuais, táteis, sistematizados ou não no contexto cultural. Performance, na definição de Zumthor, é

[...] a ação complexa pela qual uma mensagem poética é simultaneamente, aqui e agora, transmitida e percebida. Locutor, destinatário, circunstâncias (quer o texto, por outra via, com a ajuda de meios linguísticos, as represente ou não) se encontram concretamente confrontados,

${ }^{9}$ Ao longo de sua carreira, Caterina promoveu muitos músicos talentosos que, posteriormente, construíram uma carreira autônoma como intérpretes. É o caso de Maurizio Geri, Francesco De Gregori e Ricardo Tesi, que se destacaram também na interpretação do cancioneiro popular italiano.

Revista TextoPoético | ISSN: 1808-5385 | Vol. 21 (2o sem-2016) - p. 42. 
indiscutiveis. Na performance se redefinem dois eixos da comunicação social: o que junta o locutor ao autor; $e$ aquele em que se unem a situação e a tradição. (2010, p. 31-32).

Performance implica corporeidade: presença corporal manifestando um saber-ser no tempo e no espaço. "Ação (e dupla: emissão-recepção), a performance põe em presença atores (emissor, receptor, único ou vários) e, em jogo, meios (voz, gesto, mediação)" (ZUMTHOR, 2010, p. 166). Intérprete e público vivenciam um momento único, de comprometimento empírico, impossível de traduzir e de reproduzir.

A performance projeta a obra poética num cenário. No caso da canção, o lugar da performance é destacado no espaço do grupo, onde integram-se elementos como palco, efeitos de luz, adereços, móveis, objetos, instrumentos musicais, etc. Dentro desse cenário, um primeiro elemento que se apresenta é o intérprete que, através do corpo (voz, expressão facial, gestos) e, eventualmente, de outros elementos visuais relacionados ao corpo (vestimenta, adereços, maquiagem), atribui forma ao texto. Daí, na prática da poesia oral, o papel do intérprete ganhar mais destaque que o próprio compositor da obra, como argumenta Zumthor:

Em toda prática da poesia oral, o papel do executante conta mais que o do compositor. Não que ele o ofusque completamente; mas, manifesto na performance, contribui mais para determinar as reações auditivas, corporais, afetivas do auditório, a natureza e a intensidade de seu prazer. A ação do compositor, preliminar à performance, encontra-se numa obra ainda virtual. (2010, p. 236).

Mesmo nas obras em que a autoria é desconhecida, como é o caso das duas canções apresentadas aqui, a performance jamais é

Revista TextoPoético | ISSN: 1808-5385 | Vol. 21 (2o sem-2016) - p. 43. 
anônima. Assim como nas velhas civilizações orais, o público associa espontaneamente uma canção ao nome daquele que a executou em determinadas circunstâncias, ou seja, "[...] adota para $\mathrm{o}$ intérprete o mesmo comportamento que adota para o autor: a lembrança e o título de uma canção se prendem ao nome de um dos seus cantores que a propagam, a ponto de parecer como coisa sua" (ZUMTHOR, 2010, p. 239). Pelo fato de Caterina Bueno ter recuperado e interpretado uma canção quase esquecida, dando-lhe nova existência, comumente a autoria de Italia bella mostrati gentille é atribuída a ela.

A atuação de um intérprete, durante a performance, varia conforme haja acompanhamento musical, outros intérpretes e características do público. Ele pode variar espontaneamente o tom, a enunciação, a gestualidade, de acordo com a expectativa que percebe no público. Uma prática comum de Caterina Bueno, em situações de performance, era tecer um breve comentário antes de iniciar a canção, explicando onde e em que circunstâncias havia sido recolhida e de que tema tratava. Dessa forma, as canções entoadas, preservando o dialeto original, eram contextualizas para os ouvintes.

O ouvinte também é um elemento constitutivo da performance, e seu papel é tão importante quanto o do intérprete. De acordo com Zumthor (2010), a recepção da poesia oral é um ato único, fugaz, irreversível e individual. Assim, a mesma performance nunca é experienciada de forma igual por dois ouvintes, já que a recepção da poesia oral é condicionada pela interpretação de cada sujeito no exato momento da performance. É nessa perspectiva que o ouvinte assume um duplo papel: de receptor e de coautor do texto.

Revista TextoPoético | ISSN: 1808-5385 | Vol. 21 (2o sem-2016) - p. 44. 
A componente fundamental da "recepção" é assim a ação do ouvinte, recriando, de acordo com seu próprio uso e suas próprias configurações interiores, o universo significante que lhe é transmitido. As marcas que esta recriação imprime nele pertencem a sua vida intima e não se exteriorizam necessária e imediatamente. (ZUMTHOR, 2010, p. 258).

Além disso, a forma da poesia oral é percebida em performance, mas situada no aqui e agora, a cada performance ela se transforma. Sendo a canção tomada pelo domínio da voz, em toda sua multiplicidade e mutabilidade, ela tende a ser retransformada por quem canta a cada nova interpretação (FALBO, 2010).

A voz incomum de Caterina Bueno, ao mesmo tempo profunda e sensual, constitui uma característica estética significativa, diferenciando-se das vozes femininas da tradição oral italiana, mais agudas e estendidas. Essa característica define a diferença entre a canção registrada (o documento recolhido etnograficamente), por um lado, e a invenção artística de Caterina realizada em performance, de outro (GIORGI; SPINELLI; MASOLINI, 2013). As canções, assim, transformam-se em porta-vozes de sua autonomia enquanto intérprete e da afirmação de sua personalidade libertária.

Neste momento, a obra de Caterina Bueno nos chega apenas de forma mediatizada, por meio de discos (voz) e alguns vídeos (voz e imagem). Não é possível analisá-la enquanto performance, pois não estamos vivenciando, aqui e agora, a experiência concreta. Não estamos na presença dos corpos, intérprete e público, e todos os demais elementos constitutivos da performance. A mediação eletrônica, fixando a voz e a imagem, torna-a abstrata, abolindo sua

Revista TextoPoético | ISSN: 1808-5385 | Vol. 21 (2o sem-2016) - p. 45. 
tactilidade (ZUMTHOR, 2007). Sobre a utilização das mídias, o teórico considera que,

Fixando o som vocal, elas permitem sua repetição indefinida, excetuando-se qualquer variação. Decorre daí um considerável efeito secundário: a voz se liberta das limitações espaciais. As condições naturais do seu exercício se acham assim alteradas. A situação de comunicação, por sua vez, sofre mudanças de forma desigual em sua performance. (ZUMTHOR, 2010, p. 27).

A obra executada aqui e agora envolve por inteiro o ouvinte, porém, na poesia oral mediatizada, alguma coisa sempre lhe escapa. Na performance mediatizada, a participação propriamente dita, a identificação coletiva com a mensagem recebida ou com seu emissor cede lugar a uma identificação solitária com o modelo proposto.

De acordo com Zumthor (2010), o arquivamento da poesia oral, por escrito ou gravação eletrônica, fundamenta seu modo de existir fora da performance, determinando sua conservação. O arquivo captura-a no momento de uma performance. Assim, estabilizada, a poesia oral perde o movimento vital, mas conserva a capacidade para suscitar outras performances. Já não temos a presença física de Caterina Bueno entre nós, mas a sua obra, preservada em arquivo, permite que ouvintes de outro espaço e de outro tempo vivenciem, de forma mediatizada, a performance. Os meios eletrônicos permitem, assim, que a sua obra tenha um alcance ainda maior.

De fato, é no âmbito do ouvinte e da recepção que se manifesta a verdadeira dimensão histórica da poesia oral. A força constitutiva da poesia oral define-se pela função que assume no grupo social. No caso das canções abordadas aqui, a intenção que animou a criação proveio de uma circunstância vivenciada coletivamente: a emigração. Um acontecimento que afetou o conjunto de uma Revista TextoPoético | ISSN: 1808-5385 | Vol. 21 (2o sem-2016) - p. 46. 
comunidade com um peso de significação que a poesia oral expressou e tornou perceptível. No entanto, o fato social que motivou as canções Italia bella mostrati gentille e Il Sirio ficou no passado. Quando Caterina Bueno as recupera e as interpreta em performance, essas canções já estão apartadas da circunstância da emigração. Da mesma forma, o público que as ouve já não é o grupo social que vivenciou o ocorrido, logo, as canções assumem outra função social, distinta da que originalmente desempenharam. O que restou foi a lembrança de um passado histórico comum, um elo que une um grupo social e que tem sua identidade reafirmada pela poesia oral. O que Zumthor (2010) designa como um eixo da força constitutiva de um gênero oral: sua finalidade imediata e explícita, quando ela se identifica com a vontade de preservação do grupo social, neste caso, evocando algum acontecimento do passado que já teve importância para a comunidade.

As canções são atualizadas pela performance e ressignificadas por ouvintes que não viveram a experiência da emigração. Pela voz única de Caterina Bueno, a cada performance, também única, essas canções são transpostas para um novo contexto, cabendo aos ouvintes revestirem-nas de novas significações. Por um lado, elas podem evocar as vozes dos antepassados, as histórias dos avós, uma nostalgia, a reverência a um passado de sofrimento ou o louvor à coragem de um povo. Por outro, emocionam pela própria melodia, o ritmo ressoa destacando-se do texto; a música, então, embala o corpo, despertando as mais diversas sensações. De outra maneira ainda, ao escutá-las, os ouvintes de hoje podem relacionálas a uma experiência não mais coletiva, mas individual, significando o fato de viver por algum tempo fora do seu país de origem ou comovendo-se com a situação dos milhares de refugiados

Revista TextoPoético | ISSN: 1808-5385 | Vol. 21 (2o sem-2016) - p. 47. 
africanos ou asiáticos que, salvo os diferentes contextos, atravessam o mar e repetem a epopeia dos migrantes italianos na busca de um recomeço em um novo continente.

De uma maneira ou outra, a poesia oral responde às expectativas de cada ouvinte. É nesse sentido que a performance desempenha papel fundamental na construção de significados, podendo transformar completamente o sentido primeiro de uma canção:

Liberada, portanto, aos caprichos do tempo, a obra poética oral oscila na indeterminação de um sentido que ela não cessa de desfazer e recriar. O texto oral pede uma interpretação também movente. A energia que o sustém e compõe suas formas, a cada performance, recupera a existência vivida e a integra a seu material. As questões que o mundo lhe colocam não cessam, por sua vez, de se modificar; bem ou mal, a obra modifica suas respostas. (ZUMTHOR, 2010, p. 292).

Manifestando-se em relação ao "horizonte de expectativa" dos ouvintes, o texto transmitido pela voz é, necessariamente, fragmentário. A poesia oral nunca se encontra esgotada, seu espaço semântico nunca pode ser preenchido inteiramente, estando sempre aberto a novas significações.

\section{A movência da obra: as canções transpostas para o Brasil}

O cancioneiro popular italiano foi trazido para o Brasil com os migrantes. No final do século XIX e durante as primeiras décadas do século XX, os imigrantes passaram a viver no Brasil um modo de vida semelhante ao de seu país de origem, seja pelo isolamento inicial, seja pelo convívio quase restrito com grupos que se identificavam entre si socioculturalmente, e o canto desempenhou

Revista TextoPoético | ISSN: 1808-5385 | Vol. 21 (2o sem-2016) - p. 48. 
papel fundamental na manutenção de sua identidade e como aporte subjetivo frente às adversidades do processo migratório.

Zumthor (2010) confirma que a maioria dos casos em que uma canção ultrapassa os limites geográficos ou linguísticos onde se situa originalmente ocorre em situações que envolvem deslocamentos de grupos em grande escala, como rotas de migração, de comércio, de peregrinações. $\mathrm{O}$ isolamento inicial em que viveram os imigrantes no início da colonização permitiu ao grupo, em certa medida, conservar sua coesão, sua língua e um pouco de sua poesia oral.

Importados, esses poemas podem se manter muito tempo numa forma pouco alterada. Mas a necessidade que faz com que sobrevivam nas pequenas comunidades de imigrantes trabalha seu interior e, ao fim, os transforma. Em torno dessas relíquias se reconstroem novas tradições que, mantendo alguns de seus traços primeiros, se desenvolvem segundo um ritmo e tendências outras. (ZUMTHOR, 2010, p. 279)

Entre as canções populares italianas, as que se reportam à imigração e as canções napolitanas são as mais conhecidas no Brasil. Segundo Caprara (1999), geralmente são canções entoadas em coro, sem autoria definida, algumas são conhecidas em diferentes versões devido ao modo, ao período ou ao lugar de onde foram recolhidas da viva voz dos cantores, transmitidas de geração a geração, voz autêntica dos sentimentos de uma parte da população que tinha na oralidade a forma principal de expressão. De acordo com Zumthor (1993), em uma comunidade em que predomina a oralidade como forma de comunicação, a voz poética desempenha uma função coesiva e estabilizante sem a qual o grupo social não poderia sobreviver.

De fato, os estudos de Ribeiro e Porto (2015) sobre a Região Colonial Italiana (RCI) no Rio Grande do Sul apontam que o canto teve função vital no contexto dos primeiros imigrantes e seus

Revista TextoPoético | ISSN: 1808-5385 | Vol. 21 (2o sem-2016) - p. 49. 
descendentes, na busca de um equilíbrio para enfrentar as dificuldades do dia a dia, além da função de agregação social. Cantavam para se divertir, mas também cantavam a fome, a miséria, as condições de vida e de trabalho, as injustiças e preconceitos, a saudade da terra, a casa e a infância, enfim, praticamente todos os aspectos do viver. Eram canções em sua grande maioria no dialeto de origem do imigrante, a que se somavam os cantos religiosos de função litúrgica ou paralitúrgica, em latim e em italiano. Esse repertório foi ampliado pelos cantos das diferentes províncias de origem dos imigrantes e pelo acréscimo de alguns cantos compostos na própria região de colonização. No entanto, segundo as autoras, esse repertório modificou-se. Muitas canções desapareceram, como ocorreu praticamente com os cantos, rimas e jogos infantis e algumas canções de ninar, além dos cantos dela stela, que eram cantados à época do Natal, do Ano-Novo até a Epifania, permanecendo apenas fragmentos de versos na memória dos mais velhos, que já não sabem cantá-las. Por outro lado, alguns cantos líricos, satíricos, narrativos, que exercem a função de cantos de agregação social podem ser ouvidos ainda hoje. São cantos de conteúdo e estrutura diversos, cantados nas reuniões sociais familiares ou de amigos, nas festas das comunidades ou explorados como atração turística nas cidades em que se valoriza o histórico da imigração italiana.

Dentre as canções da emigração ${ }^{10}$, Italia bella monstrati gentille não é muito lembrada no Brasil. Trata-se de uma canção recolhida na Toscana, região em que a emigração não foi tão intensa

\footnotetext{
${ }^{10}$ As canções representativas da grande emigração do final do século XIX mais conhecidas no Brasil são Santa Lucia Lontana, Mamma mia dammi cento lire, Trenta sei giorni di nave a vapore (também conhecida como Mérica, Mérica) e Il Sirio.
}

Revista TextoPoético | ISSN: 1808-5385 | Vol. 21 (2o sem-2016) - p. 50. 
quanto nas regiões do norte da Itália, ainda mais afetadas pela crise econômica. Além disso, o texto representa o ponto de vista não daqueles que já haviam partido para a América, mas daqueles que ainda resistiam em deixar o país. Diferentemente da primeira, Il Sírio é uma canção bastante conhecida no Brasil, e pode ser ouvida ainda hoje em determinados contextos, performatizada por diferentes intérpretes.

As canções se movem num espaço poético amplo. De uma geração a outra, tanto a melodia quanto o texto podem variar. Para uma canção podem existir diferentes versões, e letras novas podem ser inventadas para antigas melodias. O caso da canção Il Sirio é exemplar. São conhecidas no Brasil diferentes versões que trazem pequenas alterações textuais. Também há uma variante que, mantida a melodia, teve inscrito um novo texto em outra língua:

\section{Il Sirio ${ }^{11}$}

Quando da Genova

il Sirio partiva

per L'América

al suo destino.

\section{A morte do tropeiro ${ }^{12}$}

À beira da estrada, No desfiladeiro, $\mathrm{O}$ invicto tropeiro Ferido tombou.

${ }^{11}$ Tradução: Quando de Gênova / o Sirio partia / para a América / ao seu destino. / Sem medo / o Sírio corria / leve e rápido / no plácido mar. / Oh Sirio, oh Sirio / oh equipe miserável / para muita gente / o miserável fim / Em alto mar / o navio quebra / de encontro / à pedra fatal / Quatro barcos / na água corriam / vão em socorro / dos nossos irmãos / Entre aqueles náufragos / os padres rezavam / e depois lhes davam / a bênção / Pais e mães / beijavam seus filhos / depois desapareciam / nas ondas do mar.

${ }^{12}$ Essa versão consta no livro ...E cantavam, de Giuseppe Corradin et. al. (1972, p. 19).

Revista TextoPoético | ISSN: 1808-5385 | Vol. 21 (2o sem-2016) - p. 51. 
Senza timore

il Sirio correva

legger leggero

sul plácido mar.

O Sírio, Sírio,

la misera squadra

per molta gente

la misera fin.

Sull'Alto mare

la nave s'infranse

Incontrando lo

scoglio fatale.

Quatro barchette

scorrevan sull'acqua

va in soccorso

dei nostri fratelli.

Tra quei naufraghi

i preti pregavano

e poi lor davano

la benedizione

Padri e madri

bacciavano i figli

poi sparivano

tra le onde del mar.
Brioso montado

Seguro tangia

A tropa bravia

Té as bandas do mar.

"Um círio, um círio"

É a última prece

Com que adormece

Na paz do Senhor.

No estouro da tropa,

Após a rodada,

Em louca abalada,

A rês o investiu.

Vê perto o cavalo,

Seu dócil amigo,

Que em meio ao perigo,

Primeiro caiu.

Saudades mil deixa

À sua mãezinha,

Que longe definha,

Por ele a temer.

A noiva lembrando

No seu vilarejo,

Envia-lhe um beijo

No último adeus.

Adaptando o texto ao cenário do Rio Grande do Sul, dois sacerdotes da Diocese de Caxias do Sul, Dom José Barea e o Monsenhor João Meneguzzo, compõem a letra $A$ morte do tropeiro, em língua portuguesa, inserindo elementos da tradição gaúcha como o perigoso trabalho do tropeiro que conduz o rebanho, tendo no cavalo um fiel amigo. Sem deixar de fazer um apelo à religiosidade, o nome do navio, Sírio, converte-se em Círio, um dos símbolos da Igreja Católica. A palavra homófona refere-se à grande vela de cera

Revista TextoPoético | ISSN: 1808-5385 | Vol. 21 (2o sem-2016) - p. 52. 
usada nas igrejas ou em procissões. A canção, assim, reveste-se de um novo significado, distanciando-se totalmente do sentido da canção que a originou.

É o que Zumthor denomina de movência da obra, manifestada por diferenças de toda espécie e amplitude, textuais, melódicas ou rítmicas, na ação performática. Criação contínua, a memória não cessa de recriar os sentidos:

Na medida mesma em que o intérprete empenha assim a totalidade de sua presença com a mensagem poética, sua voz traz o testemunho indubitável da unidade comum. Sua memória descansa sobre uma espécie de "memória popular" que não se refere a uma coleção de lembranças folclóricas, mas que, sem cessar, ajusta, transforma e recria. $O$ discurso poético se integra por ai no discurso coletivo, o qual ele clareia e magnifica. (ZUMTHOR, 1993, p. 142).

Inerente à performance, a variação da obra poética pode ocorrer, de forma intencional ou inconscientemente, vinculada ao estilo de cada intérprete ou da época, às convenções sociais, à expectativa do público. Geralmente, os textos mais móveis são os menos formalizados, como os narrativos.

É a movência da poesia oral, portanto, que garante a permanência das canções na memória do grupo social, justamente porque, a cada performance, a obra é atualizada. Antigas canções, por meio de novas interpretações, adquirem novos sentidos; melodias quase esquecidas ganham uma nova existência.

Revista TextoPoético | ISSN: 1808-5385 | Vol. 21 (2o sem-2016) - p. 53. 


\section{Considerações finais}

A canção evocando a nação perdida ou a tragédia no mar provoca no ouvinte uma reação afetiva bem mais intensa que o falado em uma frase comum. Como forma de poesia oral, as canções Italia bella mostrati gentille e Il Sirio ultrapassam o fato histórico que as motivou, sendo ressignificadas a cada performance. $\mathrm{O}$ sentimento de um determinado grupo social, expresso pela voz, recuperado e trazido para o contexto atual por meio dos recursos mediáticos, permite novas interpretações, atribuindo significado a novas experiências. Por meio da força expressiva da vocalidade, essas canções tocam, emocionam, comovem ouvintes de outro espaço-tempo, respondendo às inquietações mais recônditas de cada um. Já não são mais o canto dos emigrantes; o ouvinte de qualquer extrato social apropria-se delas e preenche-lhes o sentido. É nessa perspectiva que a oralidade funda o texto poético, transpondo as barreiras entre o popular e o erudito, não se circunscrevendo a classes sociais.

A poesia oral constitui, num sentido amplo, um elemento indispensável da sociabilidade humana, um fator essencial da coesão dos grupos. É, em última instância, a função da própria literatura, na medida em que coloca os indivíduos em contato com aquilo que os constitui enquanto seres humanos: os sentimentos e emoções vivenciados pelo homem de qualquer espaço, de qualquer época. Por meio da literatura nos reconhecemos e dialogamos, independentemente das circunstâncias geográficas ou históricas que nos separam.

Pensar o cancioneiro popular italiano como uma forma de poesia oral é valorizar seu poder expressivo, na busca pela

Revista TextoPoético | ISSN: 1808-5385 | Vol. 21 (2o sem-2016) - p. 54. 
reintegração da linguagem corporal à literatura, tão saturada pela escrita. Pela ação da voz, devolve-se à literatura a integridade físicopsíquica de um corpo, pleno de sentidos. A obra poética realizada em performance apresenta-se, assim, como produção do corpo, restabelecendo à mensagem uma força expressiva que, ao longo do tempo, foi sendo cada vez mais reprimida pela primazia que a civilização ocidental atribuiu à escrita.

\section{Referências}

CAPRARA, L. Cultura e língua italiana nas músicas populares dos séculos XIX e XX. 2. ed. São Paulo: Humanitas/FFLCH/USP, 1999.

CORRADIN, G. et al. ...E cantavam: coleção de cantos populares da Região de Imigração Italiana no RS. Porto Alegre: CIBAI, 1972.

DE BONI, L. A.; COSTA, R. Os Italianos do Rio Grande do Sul. Porto Alegre: Escola Superior de Teologia São Lourenço de Brindes; Caxias do Sul: Universidade de Caxias do Sul, 1979.

FALBO, C. V. R. A palavra em movimento: algumas perspectivas teóricas para a análise de canções no âmbito da música popular. Per Musi, Belo Horizonte, n. 22, 2010, p. 218-231.

GIORGI, P.; SPINELLI, F.; MASOLINI, S. Caterina Bueno: inventario del fondo documentario. Firenze: Consiglio Regionale della Toscana, 2013.

RIBEIRO, Cleudes P. J.; PORTO, Patrícia P. O Cancioneiro popular da imigração italiana. Universidade de Caxias do Sul. Disponível em: $<$ http://ler.letras.up. pt/uploads/ficheiros/10379.pdf.>. Acesso em: 14 jul. 2015.

ZUMTHOR, P. A letra e a voz: a "literatura" medieval. São Paulo: Companhia das Letras, 1993.

Revista TextoPoético | ISSN: 1808-5385 | Vol. 21 (2o sem-2016) - p. 55. 
.Performance, recepção, leitura. 2. ed. São Paulo: Cosac Naify, 2007.

. Introdução à poesia oral. Belo Horizonte: Editora UFMG, 2010.

Aprovado em 27 de fevereiro de 2016.

Revista TextoPoético | ISSN: 1808-5385 | Vol. 21 (2o sem-2016) - p. 56. 